\title{
4
}

\section{Creating Consumer-Citizens: Competition, Tradition and the Moral Order of the Mobile Telecommunications Industry in Fiji}

\author{
Heather A. Horst
}

On 1 October 2008, Digicel Fiji launched its new mobile network in Albert Park in the nation's capital Suva. Described by many Fijians as 'spectacular', the company held a free concert that featured Jamaican reggae artist Sean Kingston and New Zealand's reggae band Katchafire. The launch was attended by approximately 60,000 Fijians, ${ }^{2}$ a significant

\footnotetext{
1 This chapter was supported by an Australian Research Council Discovery Project DP140103773, The Moral and Cultural Economy of Mobile Phones in the Pacific. I thank my colleague Robert Foster for constructive comments on the chapter at a pivotal point as well as feedback from seminar participants at the School of Government, Development and International Affairs (SGDIA) Seminar Series at the University of the South Pacific in October 2017, the Digital Ethnography Research Centre at RMIT University in August 2016 and the Department of Media and Communications (MECO) Seminar Series at the University of Sydney in 2016. While Digicel Group has permitted the use of its images and artwork, the views, opinions and research expressed in this chapter are those of the author and do not necessarily reflect the official policy or position of Digicel Group or any of its affiliates and entities. The chapter also does not reflect the views and opinions of Vodafone Fiji or any of its affiliates or entities.

2 The trend of launching with Jamaican and Caribbean music stars has been carried out in Tonga and Vanuatu with Jamaican Shaggy in Tonga and Burmudan Collie Buddz who played centre stage in Vanuatu.
} 
crowd given the population of greater Suva in 2008 (est. 400,000), and Digicel Fiji offered promotions for free phones to the first 100 customers and FJ $\$ 75$ (US\$45) free credit. The company also took out full-page ads in the two main national newspapers, The Fiji Times and Fiji Sun, a day that is widely recognised in the local newspaper industry as breaking records for advertising income thanks to both Digicel Fiji and the nation's incumbent mobile network provider, Vodafone Fiji. In addition, the press conference for the launch was featured on various nightly news programs.

The launch was followed up with Caribbean-style 'roadshows' where caravans of vehicles with loudspeaker systems moved throughout the country announcing the company's arrival in Fiji and associated promotions to entice new consumers to their mobile network. Throughout the events leading up to and after the launch, Digicel Fiji emphasised its cross-island coverage, especially the expansion of its mobile network coverage in the rural and remote areas of Fiji. The company also proudly highlighted its hard-earned reputation for introducing competition and the subsequent reductions in market prices across their markets in the Caribbean, Central America and South Pacific. Indeed, FijiOne's coverage of Digicel Fijis launch honed in on Digicel's claim to being 'monopoly breakers' who bring 'open competition' at all costs. As one of the Irish representatives of Digicel Fiji declared during the launch, 'we're not afraid to bring it on' (Fiji Broadcasting Corporation 2008).

Digicel Fijis emphasis upon breaking up monopolies and reducing prices framed the company as introducing a new moral order to Fiji, one that is widely recognised in global capitalism and resonates with the kinds of discourses of rupture, change and transformation associated with market capitalism (Miller 1997; Miyazaki 2006; Polanyi 1944; Shankar and Cavanaugh 2012; Thompson 1991). This chapter examines the ways in which liberalisation and the promise of competition has shaped the telecommunications landscape in Fiji by analysing the branding strategies leading up to and immediately following the launch of Digicel Fiji in 2008. Through close attention to these campaigns and the discourses of change that surrounded them, I argue that liberalisation transformed Vodafone Fiji and Digicel Fiji from mere mobile telecommunications companies providing products and services into moral actors responsible for articulating their responsibilities towards Fiji and Fijians as consumercitizens. Focusing upon the different forms of moral order created by companies engaging with state agencies as well as consumers, I begin by outlining the ways in which Digicel framed itself as a monopoly breaker 
that would disrupt existing moral relationships between the incumbent and consumers by offering better and more widespread coverage and affordable prices. I then turn to the incumbent Vodafone Fiji's efforts to both anticipate and respond to the call for a new moral order (Callon, Méadel and Rabeharisoa 2002; Foster 2007, 2011; Slater 2011). In the final section I examine the ways these market conditions and the moral orders associated with them were depicted to the company's current and future mobile consumers.

\section{Competition and Tradition: Competing Moral Orders}

As Thompson has argued, the moral economy is based upon 'a consistent traditional view of social norms and obligations [that are] supported by the wider consensus of the community' (Thompson 1991: 188). This section examines the ways in which Digicel and Vodafone marketed transformations in the availability of mobile services - and their associated moral orders - to the consumers and citizens of Fiji (Rutz 1987). As Banet-Weiser (2012) and others have noted, the emergence of brands and branding cultures moves beyond the shift to commodification to offer immaterial products such as emotion and affect as well personalities and values, factors that have become essential to the inner workings of global capitalism. Through these branding activities, users are transformed into consumers and citizens, or consumer-citizens, who use the products of a particular company and come to identify with the brand that produces or distributes a particular product (Couldry 2004; Livingstone, Lunt and Miller 2007). While efforts to brand do not always result in the effects that media scholars and advertisers imagine, advertising and branding do have the potential to shape aspiration and imagination as well as the material conditions of the intended recipients (Comaroff and Comaroff 2009; Dávila 2008; Horst 2014; Mazzarella 2003). Indeed, as Shankar and Cavanaugh (2012: 359) suggest, 'Message, vital to politics as well as advertising, pairs language with materialised forms of affect and emotion in ways that foster identification'. In what follows, I explore how Digicel and Vodafone attempted to establish themselves in Fiji by creating a moral order through which Fijians could begin to recognise themselves as consumer-citizens. 


\section{The Digicel Difference: Competition and Value as Moral Order}

In almost every country that Digicel entered in order to create a new market, it worked to quickly become a visible feature of public culture through its ubiquitous billboards, extensive marketing programs and, especially, introduction of prepaid services. The company placed high value on its ability to understand and 'respect' diverse cultures while still being attuned to profit (Creaton 2010). Building upon the marketing strategies of established global telecommunications companies like Vodafone and Orange (Goggin 2006, 2010), in Fiji, Digicel undertook sponsorship of sports teams and music competitions. Not surprisingly, Digicel secured sponsorship of Rugby $7 \mathrm{~s}$; however, it began sponsoring the team nearly two years before they were awarded a licence to operate in Fiji. In effect, Digicel invested in the Fiji market long before it officially had a service to offer. In addition, it began negotiating with the National Land Trust Board to establish towers in rural and remote areas, also in advance of receiving its licence, to deliver on its promise to the regulatory authority and its claim to offer the 'bigger, better network'.

Given Digicel's aspirations, its advertising practices at the launch involved a two-pronged strategy. The first was a series of advertisements that stressed the presence and quality of Digicel's rural and remote area coverage. Figure 14, for example, is an advertisement published in The Fiji Times in October 2008 that featured what looks like a rural farmer in front of a sugarcane field. He was holding a Digicel network phone and the prominent coverage bars - four full bars - reinforced the text of the advertisement, which draws attention to the network's good or 'best' coverage. The rural scenes in these early advertisements suggested the company prioritised a population that the other network operator (Vodafone) previously ignored in building up a mobile network from the urban centres of Fiji. The second advertisement (Figure 15) was of a smiling Fijian woman - made evident for the viewer by the flower in her hair - on a beach in remote Fiji with her hair blowing in the breeze. She was wearing a tank top and lavalava (wrap) while walking and talking on the phone, gesturing the number one with her index finger. This was reinforced in capital bold letters with the phrase 'First Time', which the ad's text explained means that the woman's call went through at the first attempt. 


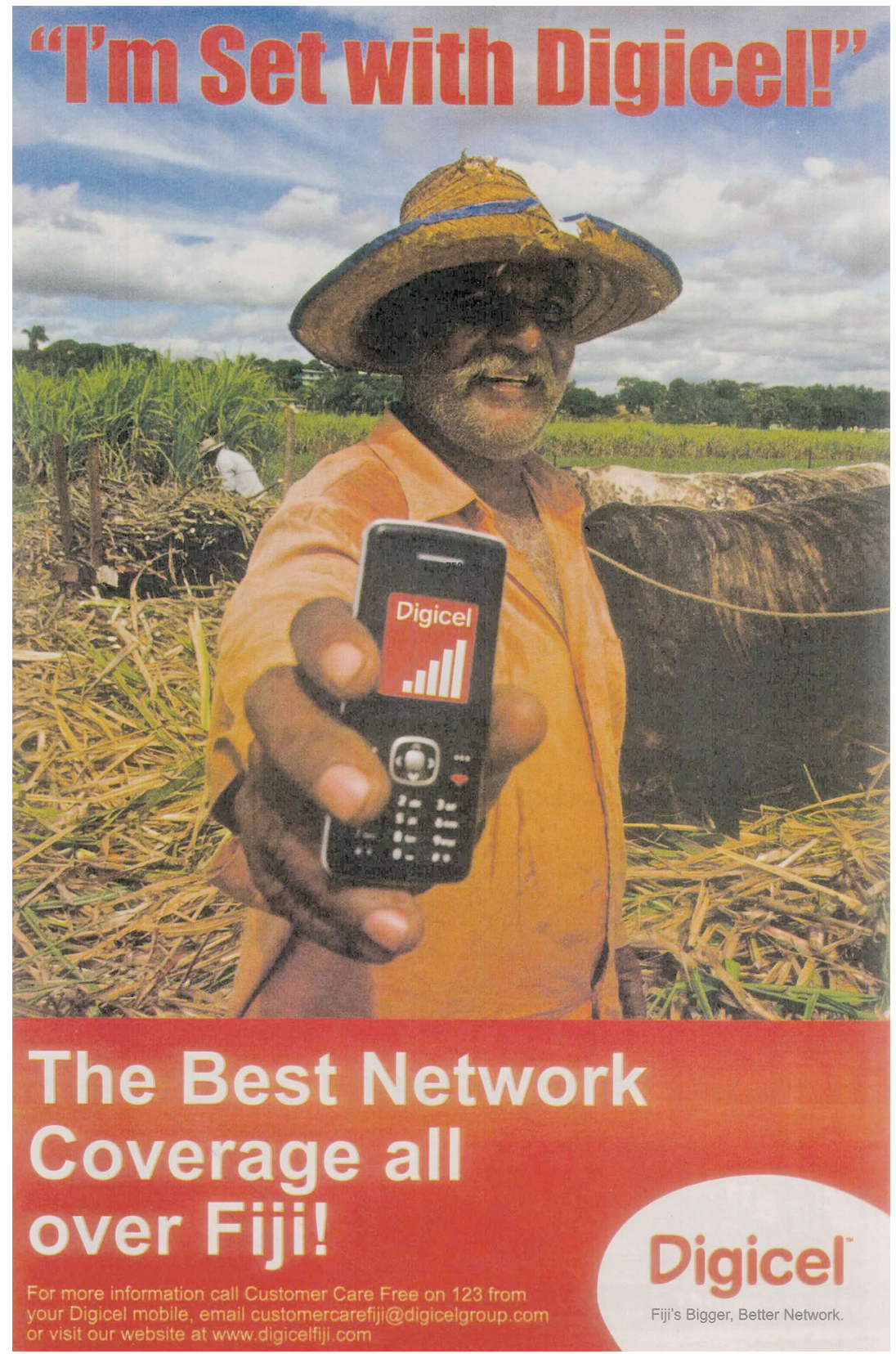

Figure 14. Photo of Digicel newspaper advertisement

Source: The Fiji Times, 16 October 2008 


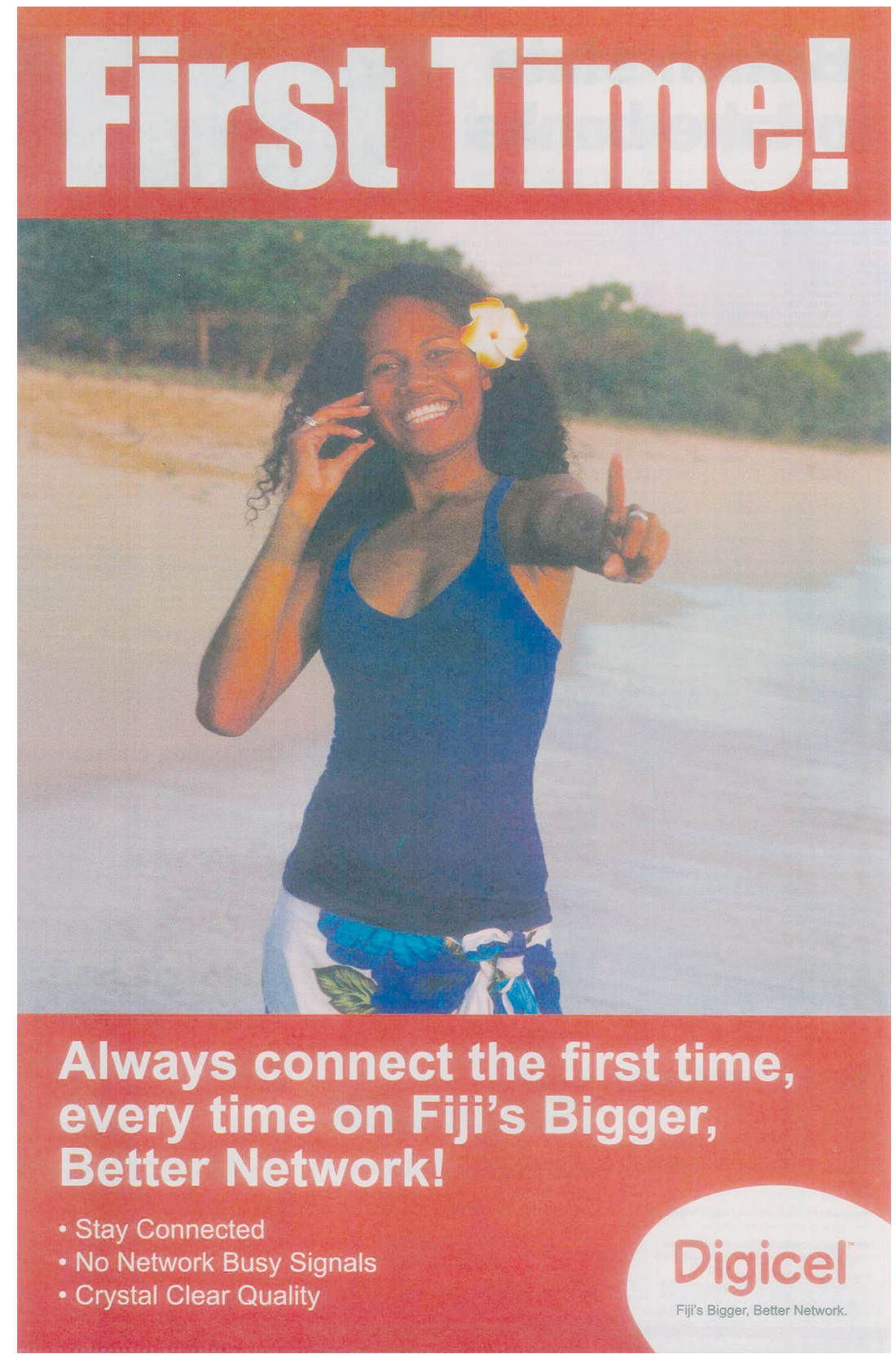

Figure 15. Photo of Digicel newspaper advertisement

Source: The Fiji Times, 14 October 2008 
The second strategy, launched on Fijian television in October 2008, featured Digicel-sponsored Rugby 7s players (Digicel Pacific 2009). The commercial began with a rugby ball branded in red Digicel letters falling towards a green island from the sky and landing in the midst of a group of women and children gathered in a rural village. A rugby player on the outside called for the ball and, once tossed over, it is clear that it's Waisale Serevi and the ball has landed on Gau Island. The ball was then tossed between Serevi, young boys and women before Serevi kicked the ball in the air to Isei Lewaqui in Nadi town, passing over a group of Indo-Fijians who were standing in front of Nadi's famous temple. Lewaqui quickly kicked it to Vereniki Goneva in Tavua town. Goneva tossed it around with Indo-Fijian kids and farmers in the sugarcane fields before kicking it on to Lepani Nabuliwaqa in Lakeba in the Lau Islands. Setefano Cakau caught the ball in Suva city before kicking it to the Yasawa Islands and it eventually landed in the hands of the entire Fiji Rugby $7 \mathrm{~s}$ team.

Whereas both launch advertisements emphasised widespread coverage, the newspaper ads (figures 14 and 15) stressed quality and value. Value in this case was not only about value for money, as exemplified by the woman whose call goes through without having to pay for a connection fee when the call drops out. It was also about the work of valuing rural populations that historically have not been prioritised in the provision of mobile telecommunication services due to the high costs of supporting remote and rural populations. The images of inclusion in the television commercial also signalled the value placed on Fijian culture. As with rugby participation in Fiji generally (Kanemasu and Molnar 2013), all the players in the videos were iTaukei. While present in the video, IndoFijians played a role in watching and participating from the sidelines (Besnier 2014). 


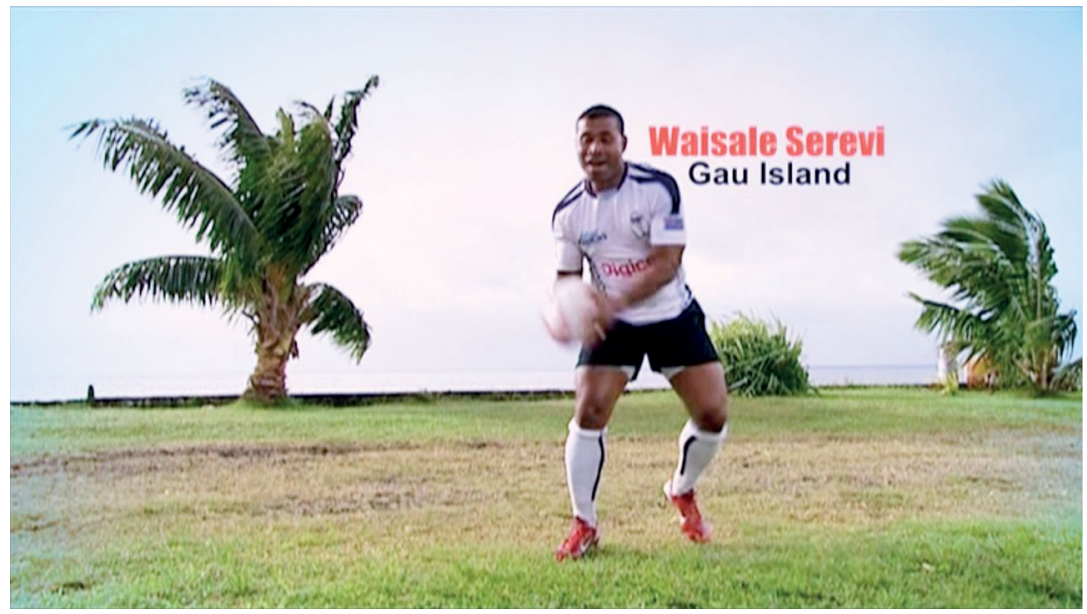

Figure 16. Digicel Fiji commercial

Source: Digicel Group Limited

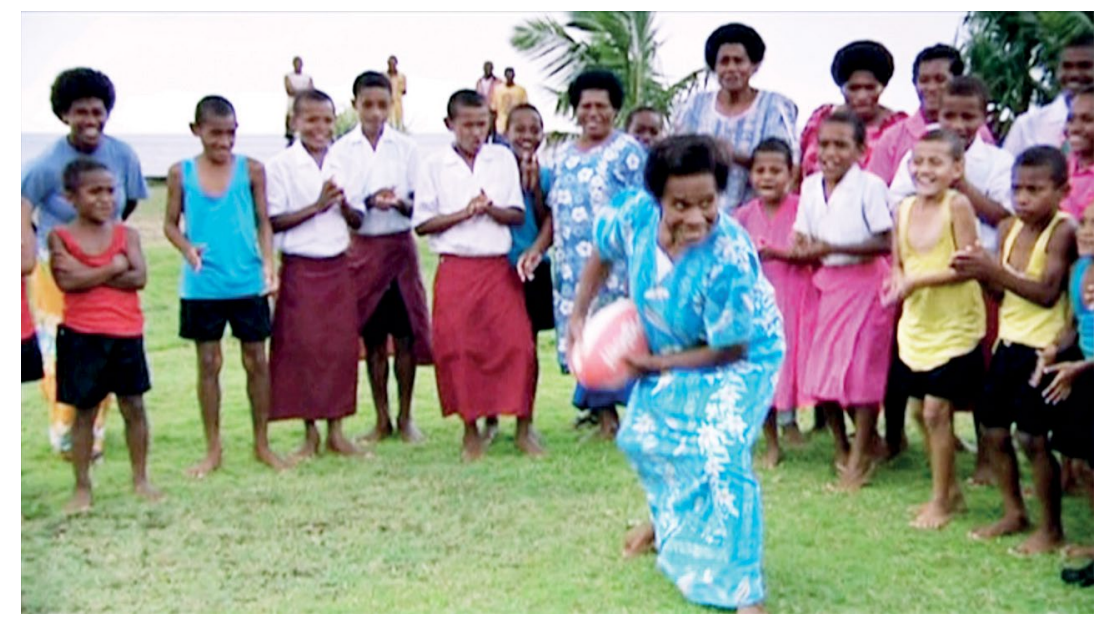

Figure 17. Digicel Fiji commercial

Source: Digicel Group Limited

The genre of using balls and other paraphernalia from national sports and sports teams is used in advertising globally and the rugby commercial was well received. Fijians recalled that they liked the commercial not only for the celebration of the Rugby $7 \mathrm{~s}$ team but also because it included a range of men, women and children from different walks of life and emphasised 'ordinary' village and city scenes. They did not, however, read The Fiji Times ad of the woman walking on the beach as favourably 
(see Figure 15). In newspaper editorials, many (self-identified) Christians noted the absence of modesty and believed that the ads should have covered the woman's shoulders and upper arms, as was the case in Digicel's rugby-themed commercial. Others posited that this was an ad directly copied from the Caribbean and was not appropriate for Fiji. Rather than solidarity with other 'island cultures', many Fijians viewed the lack of cultural specificity of these ads as patronising, as if Fijians were another set of 'brown islanders'. While not everyone was offended, the debates around imagery and representation suggest that, at that point in time, value for money and competition were clearly competing with an alternative set of values. ${ }^{3}$

\section{The Value of Vodafone: Time and Tradition}

Whereas Digicel Fiji framed its case for a new moral order in terms of the values of competition associated with global capitalism, Vodafone Fiji used the two years between application and launch of Digicel to both counteract Digicel's claim to competition as well as to reframe the negative associations that are often connected with incumbents. This was particularly noticeable in a series of marketing campaigns, the most memorable of which was released just prior to Digicel's launch in 2008: 'Vodafone Fiji Bati Song' (see Mai TV 2008).

This commercial, produced by Art and Soul Fiji, ran for two minutes and 55 seconds and played on major television stations throughout Fiji (see figures 18-21). The video began with a black-and-white image of a man walking barefoot and holding a guitar on what appears to be one of Fiji's pristine white sandy beaches. The only audible sound as the video starts is the washing of the waves until the camera pans to the musician's fingers tuning and strumming the guitar. As the musician plays the guitar, the camera moved to an image of a white flag with the Vodafone symbol blowing in the wind. The video then guides the viewer and listener through a series of timeless Fijian scenes, such as children singing and, of course, Vodafone Fiji rugby players wearing their jerseys. The song's refrain was accompanied by a bati (traditional Fijian warrior) leaping through the air

3 This continued with responses to the concert at the Digicel launch. A few days after the launch concert there was an editorial in The Fiji Times about the negative content of Sean Kingston's lyrics: 'You're way too beautiful girl. That's why it'll never work. You'll have me suicidal, suicidal. When you say it's over.' In particular, various editorials expressed disgust with the lyrics of suicide. Psychologists and others wrote in to recommend that young people speak to pastors and other members of the church for support in similar circumstances. 
wielding two drumsticks while a Fijian woman holds a drum. The song concludes with the words 'Spirit of Fiji. We are one. In body, mind and spirit we keep on, we keep strong. Take hold of your destiny from here and beyond. Fiji' while images of Vodafone employees appears between images of rugby players and the song's key vocalist.

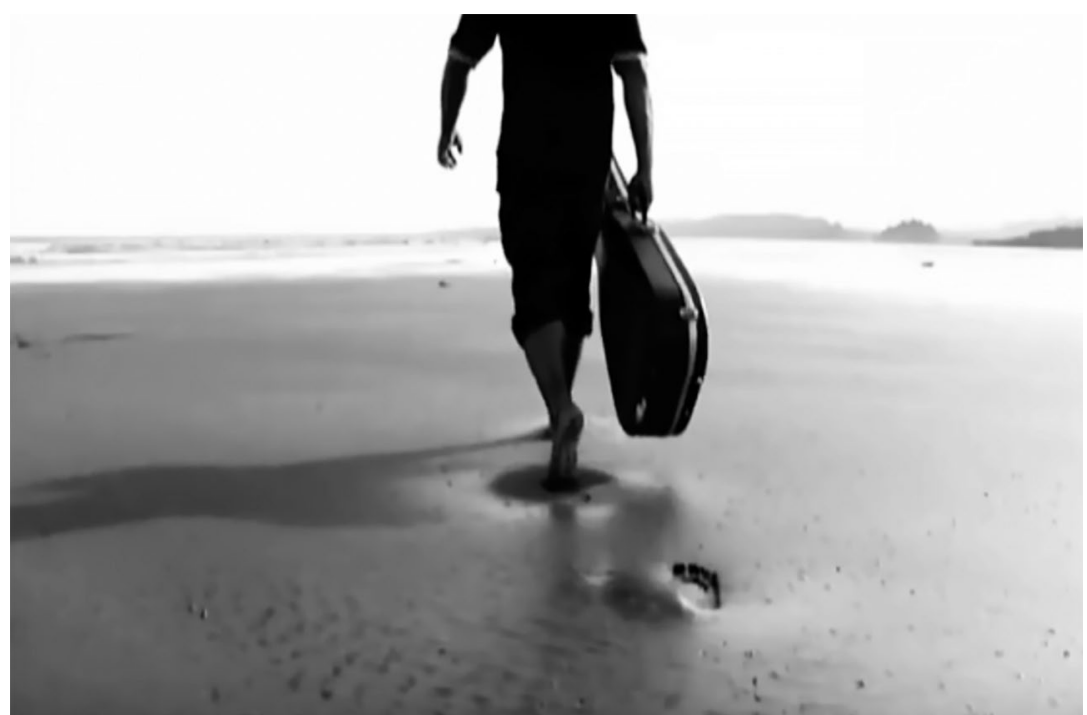

Figure 18. Opening sequence with guitar

Source: www.maitv.com.fj (Mai TV 2008)

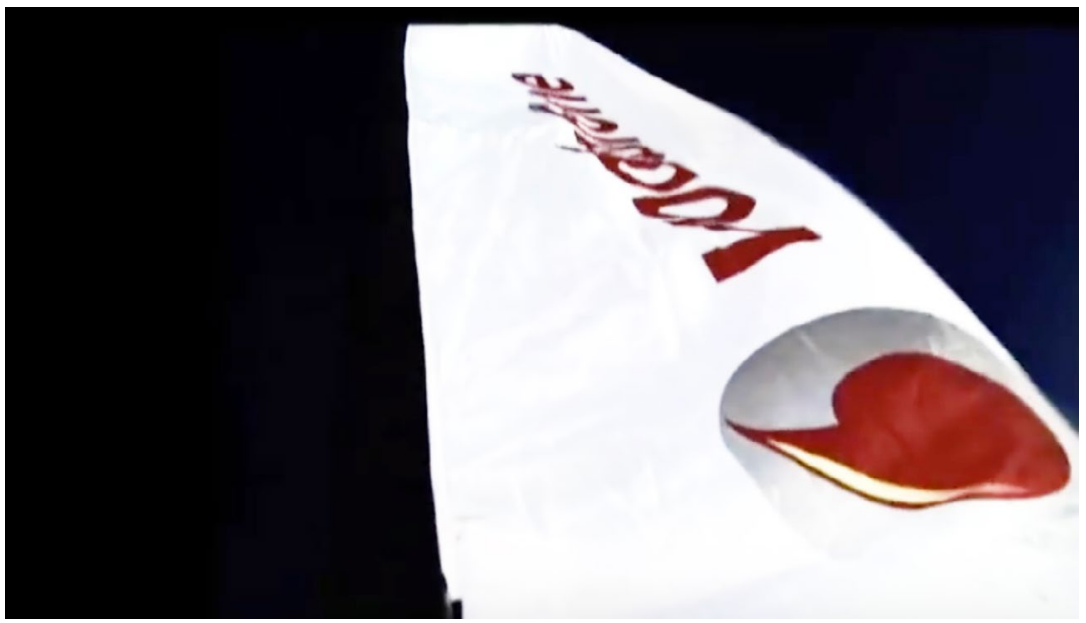

Figure 19. Vodafone Fiji Flag

Source: www.maitv.com.fj (Mai TV 2008) 


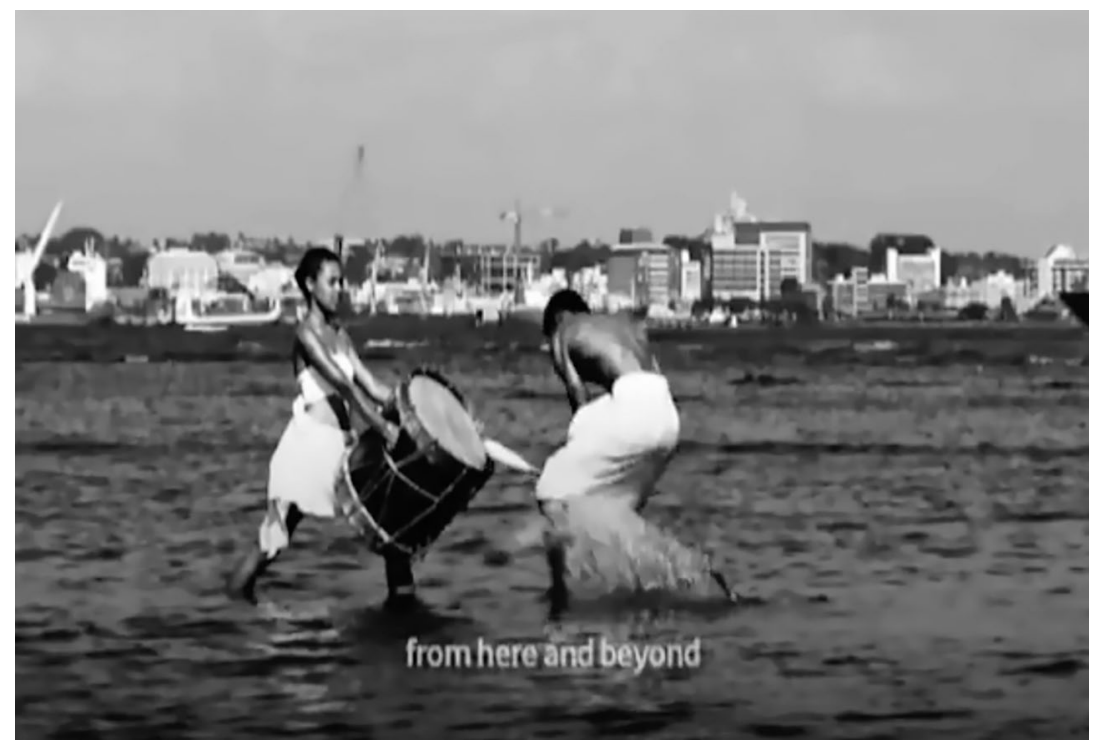

Figure 20. Fijian bati in the Vodafone commercial

Source: www.maitv.com.fj (Mai TV 2008)

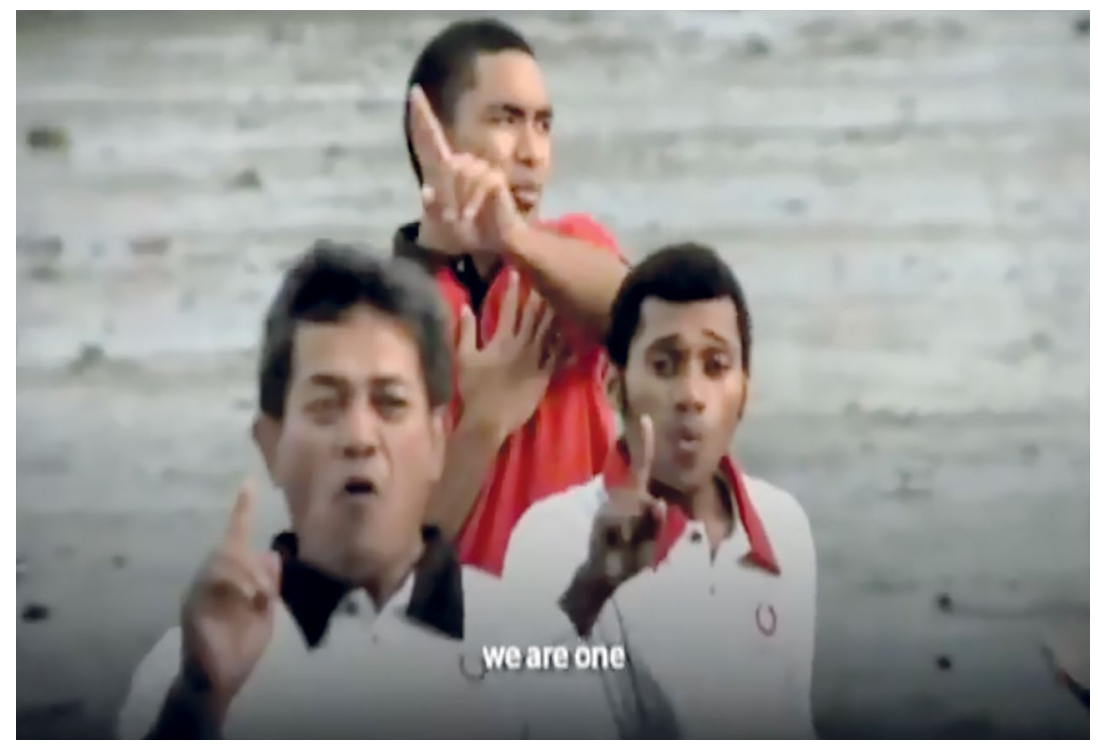

Figure 21. Vodafone Fiji employees singing

Source: www.maitv.com.fj (Mai TV 2008) 
Produced by local music artist Daniel Rae Costello, The Bati Song was performed by Talei Burns, a talented and much-loved Fijian singer. The song has become a virtual second national anthem and is still routinely played on Fiji One television, although without the Vodafone imagery. As is evident in the description, The Bati Song worked to evoke an emotional connection between Vodafone and Fijian citizens through imagery of the Fiji National Rugby Union Team, batis and the beauty of nature, as well as spirituality and Fiji's long association with Christianity (Tomlinson 2002, 2009). It also stressed unity and mutual dependence (Brison 2007). The use of black-and-white film for scenes that represent the traditions of Fiji interspersed with contemporary colour images of Vodafone-sponsored teams and employees worked to evoke a sense of timelessness and an understanding of the high value placed on tradition and culture in Fiji, which inspired a sense of pride among most Fijians who watched the video and heard the song.

\section{Consumer-Citizens and Consumer-Citizens}

From billboards, signs and radio jingles to branded T-shirts, bags and umbrellas, advertisements and associated branding strategies are designed with the aim of creating consumers and developing demand for an evolving suite of mobile-enabled services (for example, Doron and Jeffrey 2013; Goggin 2010; Horst and Miller 2006; Horst 2013; Mazzarella 2003). Advertising of various forms represents one of the most visible features of these relationships between companies and consumers (Arvidsson 2006; Banet-Weiser 2007, 2012; Ciochetto 2011; Lury 2009; Manning 2010; Mazzarella 2003; Shankar 2012, 2015). Indeed, even before its official launch, Digicel secured key billboards throughout the country, erected signs with the Digicel logo welcoming people to villages and began placing Digicel flags on flagpoles throughout the major boulevards of the country. But, as I have demonstrated here, evocative advertisements have as much cachet as the moral order that they seek to tap into and/or create.

Like other countries in the Pacific region (Meese and Mow 2006), liberalisation formally began in Fiji with an open call in 2005 for new mobile telecommunications licences that resulted in the shortlisting of four tenders and the eventual award of a licence to Digicel Limited to operate a GSM network on 26 February 2008 for a 15 -year period. Digicel paid a licence fee of US $\$ 10.25$ million (FJ $\$ 15$ million) and planned the 
investment of approximately US $\$ 80$ million (FJ $\$ 120$ million) to build the national 2G network. Fiji also became the headquarters of Digicel Pacific. The licence was also accompanied by specific conditions, such as the requirement to focus upon rural areas of the country that were largely undeveloped. This was a requirement by the Telecommunications Authority of Fiji that was designed to guarantee a competitive marketplace for both mobile telecommunications providers. Given their previous experiences in the Caribbean and Central America, Digicel also planned a significant investment in prepaid phone cards that enabled middle- and low-income individuals living in rural and urban areas to control the costs of their calls (see Horst and Miller 2005, 2006).

Vodafone Fiji launched 14 years before Digicel in July 1994 as part of the British-owned Vodafone's third global market in the Asia-Pacific region. It was the first mobile service offered in Fiji. Vodafone's only competition in the telecommunications environment previously was with the national company, Telecom Fiji Limited, which offered landline services to businesses and homes. In 1999, a 49 per cent share of Vodafone Fiji was sold to Vodafone Australia, Vodafone New Zealand and Vodafone Mobile NZ. The remaining 51 per cent stake in Vodafone Fiji was held by Amalgamated Telecom Holdings (ATH), a public company established in March 1998 as a vehicle through which the Fiji Government's investments in the telecommunications sector were consolidated for the purpose of privatisation under its public sector reform program. The ATH ownership made the parent company a minority stakeholder, part of the broader strategy of Vodafone's outreach in the region. Prior to the liberalisation of the market, Vodafone Fiji stood as the sole provider of mobile telecommunications with approximately 41 per cent of the market. ${ }^{4}$ Most Vodafone subscribers lived in urban areas and towns on the main island Viti Levu and the second largest island Vanua Levu.

For the two key mobile telecommunications players, then, creating relationships between each of the companies and their consumers, or more precisely consumer-citizens, was played out through advertising and branding strategies (Couldry 2004). As a result, the approach used by each of the companies to develop relationships with consumer-citizens

4 In July 2014, this ownership arrangement shifted again with the purchase of the remaining 49 per cent stake in Vodafone Fiji Limited by the Fiji National Provident Fund. Purchased for US\$87.9 million, the National Provident Fund is the country's main pension scheme that already had a stake in Vodafone. Now the fund has a combined ownership of 79 per cent in the mobile operator. This makes Vodafone Fiji fully locally owned. 
varied in subtle ways. Fuelled by liberalisation and the extensive and intensified advertising practices of Digicel Group globally, Digicel's entrée effectively created a commercial public sphere through which the value of consumers, companies and the nation could be negotiated. Digicel framed its moral relationship to consumers in terms of being the impetus to introduce affordable, competitive service across the island. As we see in the early advertisements by Digicel that stressed the rural and remote regions of Fiji's population, the company reframed the Telecom Authority of Fiji's requirement to develop networks in rural and remote regions as an opportunity to bring people living in these regions into the fold as mobile consumers. Like other Pacific and Caribbean markets (Horst and Miller 2006; Meese and Mow 2016), Digicel also focused on prepaid options that appealed to lower-income consumers who were unable to qualify for or maintain postpaid plans.

Vodafone, however, worked to pre-empt and, by extension, undermine Digicel's entrée, effectively chipping away at the efficacy of Digicel's moral commitment to bring down costs and assertions that the company would occupy a role as the 'monopoly breaker' in Fiji. Anticipating the impact of liberalisation on an incumbent monopoly, Vodafone filed an unsuccessful injunction against the government to prevent it from issuing further cellular licences. Alongside the injunction, Vodafone took advantage of the lead time from application to licensing to create a competitor to Digicel. Specifically, in 2007, Vodafone introduced Inkk Mobile Fiji, a subsidiary of Vodafone Fiji that offered low-cost and prepaid phone services aimed at low-income consumers. Inkk Mobile, however, does not possess a separate licence to sell mobile phones and services. While Vodafone views Inkk Mobile as a separate entity, there have also been continual challenges by Fiji's Commerce Commission around confusion of ownership of the company and conflicts of interest, including in 2010 when the Commerce Commission accused Vodafone of engaging in market abuse of power over its relationship with Inkk. From the perspective of Vodafone, which was obviously keen to maintain its market dominance, Inkk Mobile became a prepaid competitor for Digicel.

Moreover, Vodafone presented itself as part of the fabric of Fijian society, leveraging its long-term presence and commitment to Fiji. Vodafone stressed its role as incumbent and market leader by appealing to a sense of belonging, shared history and values during a period of political turbulence 
and coups (Kelly and Kaplan 2001; Norton 2012). ${ }^{5}$ In effect, Digicel's marketing strategies and promotions emphasised the 'consumer' in the consumer-citizen equation. Vodafone, by contrast, stressed its relationship with Fijians as consumer-citizens through its use of symbols of nation and belonging.

\section{Conclusion}

Whereas Digicel's entry into countries such as Jamaica, Samoa and Papua New Guinea has been transformative, resulting in rapid if not exponential rates of adoption (Horst and Miller 2006; Meese and Mow 2016; Watson and Duffield 2016), the uptake of the Digicel network and services in Fiji was less effective. This was largely due to a series of actions taken by Fiji's first mobile company, Vodafone Fiji. Unlike countries where moves toward privatisation disentangled the relationship between the incumbent telecommunications company and the state (Frempong and Atubra 2001; Gao and Rafiq 2009; Gutiérrez and Berg 2000; Howard and Mazaheri 2009), in Fiji the state has maintained a different relationship with the telecommunications companies. Given the ownership structure, it also has important relationships with various regulatory agencies, such as the Telecommunications Authority of Fiji, Fiji International Telecommunications Limited (FINTEL) and the Consumer Council of Fiji, as well as the Fiji National Provident Fund, the local pension scheme that is now majority owner of Vodafone Fiji (see footnote 4). From the perspective of some Fijians, investing in a mobile phone with Vodafone is an investment in one's pension and one's future. Digicel, by contrast, continues to be seen as a 'foreign' entity - albeit one that is now associated as much with the Caribbean as it is with Ireland. Current estimates suggest that Digicel has no more than 20 per cent of the Fijian market, one of the lowest rates of all Digicel's global markets.

For companies, brands function as a source of economic value by cultivating 'loyal customers'. Clearly, however, cultivating consumer-citizens is not just about ads and commercials. We also need to understand what might be pictured as a triangle of relationships among consumers, companies

5 Digicel has also engaged in a number of activities to become more local or 'national'. For example, in November 2010, Digicel Fiji changed its logo and applied a shade of blue to the last letters 'cel'. The blue colour represented the background colour of the Fiji flag and coincided with Digicel Fiji's new ad campaign slogan 'Fiji Matters To Us'. 
and the state. This might seem an obvious point, but there are very few accounts of mobile telecommunications that bring these three spheres together (although see Doron \& Jeffrey 2013). In most anthropological accounts, the state and company represent a backdrop for the 'meaning making' that is evident in the processes of consumption. And, for those in policy, the state and companies set the tenor of the relationship with consumers, who are often relegated to an afterthought. As we see in the case of Fiji, the cultivation of consumer-citizens is as much about the semiotics of emotion and imagery of belonging used in advertising as it is about ownership structures and regulatory bodies. Notions of national belonging are thus intertwined with telecommunications infrastructures.

\section{References}

Arvidsson, A. 2006. Brands: Meaning and Value in Media Culture. London: Routledge.

Banet-Weiser, S. 2007. Kids Rule! Nickelodeon and Consumer Citizenship. Durham, NC: Duke University Press.

2012. AuthenticTM: The Politics of Ambivalence in a Brand Culture. New York: New York University Press.

Besnier, N. 2014. Pacific Island Rugby: Histories, Mobilities, Comparisons. Asia Pacific Journal of Sport and Social Science, 3(3): 268-76. doi.org/ 10.1080/21640599.2014.982894

Brison, K. 2007. Our Wealth is Loving Each Other: Self and Society in Rakiraki Fiji. Lanham, MD: Lexington Books.

Callon, M., C. Méadel \& V. Rabeharisoa 2002. The Economy of Qualities. Economy and Society, 31(2): 194-217. doi.org/10.1080/ 03085140220123126

Ciochetto, L. 2011. Advertising and Value Formation: The Power of Multinational Companies. Current Sociology, 59: 173-85. doi.org/ $10.1177 / 0011392110391150$

Comaroff, J.L. \& J. Comaroff 2009. Ethnicity, Inc. University of Chicago Press. 
Consumer Council of Fiji 2014. Issues Paper: Problems Faced by Consumers in the Mobile Phone Sector. Suva, Fiji.

Couldry, N. 2004. The Productive 'Consumer' and the Dispersed 'Citizen'. International Journal of Cultural Studies, 7(1): 21-32. doi.org/ $10.1177 / 1367877904040602$

Creaton, S. 2010. A Mobile Fortune: The Life and Times of Denis O'Brien. London: Aurum Press.

Dávila, A. 2008. Latino Spin: Public Image and the Whitewashing of Race. New York: New York University Press.

Digicel Pacific 2009. Digicel Fiji Coverage TV Commercial. YouTube, 3 June. www.youtube.com/watch? $v=a p H T r Q U c c O Y$ (accessed 14 April 2018).

Doron, A. \& R. Jeffrey 2013. The Great Indian Phone Book: How the Cheap Cell Phone Changes Business, Politics and Daily Life. Cambridge, MA: Harvard University Press.

Fiji Broadcasting Corporation 2008. FBC News (7pm), 1 October.

Foster, R.J. 2007. The Work of the New Economy: Consumers, Brands, and Value Creation. Cultural Anthropology, 22(4): 707-31. doi.org/ 10.1525/can.2007.22.4.707

—_ 2011. The Uses of Use Value: Marketing, Value Creation, and the Exigencies of Consumption Work. In Inside Marketing: Practices, Ideologies Devices, D. Zwick \& J. Cayla, eds. Oxford University Press, pp. $42-57$.

Frempong, G.K. \& W.H. Atubra 2001. Liberalisation of Telecoms: The Ghanaian Experience. Telecommunications Policy, 25(3): 197-210. doi.org/10.1016/S0308-5961(00)00089-6

Gao, P. \& A. Rafiq 2009. The Transformation of the Mobile Telecommunications Industry in Pakistan: A Developing Country Perspective. Telecommunications Policy, 33(5): 309-23. doi.org/ 10.1016/j.telpol.2009.03.001

Goggin, G. 2006. Cell Phone Culture: Mobile Technology in Everyday Life. London: Routledge. 
2010. Global Mobile Media. London: Routledge.

Gutiérrez, L.H. \& S. Berg 2000. Telecommunications Liberalization and Regulatory Governance: Lessons from Latin America. Telecommunications Policy, 24(10): 865-84. doi.org/10.1016/S03085961(00)00069-0

Horst, H. 2013. The Infrastructures of Mobile Media: Towards a Future Research Agenda. Mobile Media and Communication, 44(1): 147-52. doi.org/10.1177/2050157912464490

2014. From Roots Culture to Sour Fruit: The Aesthetics of Mobile Branding Cultures in Jamaica. Visual Studies, 29(2): 191-200. doi.org /10.1080/1472586X.2014.887272

Horst, H.A. \& D. Miller 2005. From Kinship to Link-up: Cell Phones and Social Networking in Jamaica. Current Anthropology, 46(5): 75578. doi.org/10.1086/432650

— 2006. The Cell Phone: An Anthropology of Communication. Oxford: Berg.

Howard, P.N. \& N. Mazaheri 2009. Telecommunications Reform, Internet Use and Mobile Phone Adoption in the Developing World. World Development, 37(7): 1159-69. doi.org/10.1016/j. worlddev.2008.12.005

Kanemasu, Y. \& G. Molnar. 2013. Problematizing the Dominant: the Emergence of Alternative Cultural Voices in Fiji Rugby. Asia Pacific Journal of Sport and Social Science, 2(1): 14-30. doi.org/10.1080/216 40599.2013.798450

Kelly, J.D. \& M. Kaplan 2001. Represented Communities: Fiji and World Decolonization. University of Chicago Press.

Livingstone, S., P. Lunt \& L. Miller 2007. Citizens, Consumers and the Citizen-Consumer: Articulating the Citizen Interest in Media and Communications Regulation. Discourse \& Communication, 1(1): pp. 63-89. doi.org/10.1177/1750481307071985

Lury, C. 2009. Brand as Assemblage: Assuming Culture. Journal of Cultural Economy 2: 67-82. 
Mai TV 2008. Vodafone Fiji Bati Song. YouTube, 21 October. www. youtube.com/watch?v=R0W6HyJjjYs (accessed 14 April 2018).

Manning, P. 2010. The Semiotics of Brand. Annual Review of Anthropology, 39: 33-49. doi.org/10.1146/annurev.anthro.012809.104939

Mazzarella, W. 2003. 'Very Bombay': Contending with the Global in an Indian Advertising Agency. Cultural Anthropology, 18(1): 33-71.

Meese, J. \& I.C. Mow 2016. The Regulatory Jewel of the South Pacific: Samoa's Decade of Telecommunications Reform. Mobile Media \& Communication, 21 February. doi.org/10.1177/2050157916629707

Miller, D. 1997. Capitalism: An Ethnographic Approach. Oxford: Berg.

Miyazaki, H. 2006. Economy of Dreams: Hope in Global Capitalism and Its Critiques. Cultural Anthropology, 21(2): 147-72. doi.org/ 10.1525/ can.2006.21.2.147

Norton, R. 2012. 'A Pre-eminent Right to Political Rule': Indigenous Fijian Power and Multi-ethnic Nation Building. The Round Table, 101(6): 521-35. doi.org/10.1080/00358533.2012.749093

Polanyi, K. 1944. The Great Transformation: The Political and Economic Origins of our Times. Boston: Beacon.

Rutz, H.J. 1987. Capitalizing on Culture: Moral Ironies in Urban Fiji. Comparative Studies in Society and History, 29(3): 533-57. doi.org/ $10.1017 /$ S0010417500014717

Shankar S. 2012. Creating Model Consumers: Producing Ethnicity, Race, and Class in Asian American Advertising. American Ethnologist, 39(3): 378-91. doi.org/10.1111/j.1548-1425.2012.01382.x

—_ 2015. Advertising Diversity: Ad Agencies and the Creation of Asian American Advertising. Durham: Duke University Press.

Shankar, S. \& J. Cavanaugh 2012. Language and Materiality in Global Capitalism. Annual Review of Anthropology, 41: 355-69. doi.org/ 10.1146/annurev-anthro-092611-145811 
Slater, D. 2011. Marketing as Monstrosity: The Impossible Place between Culture and Economy. In Inside Marketing: Practices, Ideologies Devices, D. Zwick \& J. Cayla, eds. Oxford University Press, pp. 23-41. doi.org/10.1093/acprof:oso/9780199576746.001.0001

Thompson, E.P. 1991. Customs in Common. New York: New Press.

Tomlinson, M. 2002. Religious Discourse as Metaculture, European Journal of Cultural Studies, 5(1): 25-47. doi.org/10.1177/136494 2002005001154

— 2009. In God's Image: The Metaculture of Fijian Christianity, vol. 5, The Anthropology of Christianity. Berkeley: University of California Press.

Watson, A.H.A. \& L. Duffield 2016. From Garamut to Mobile Phone: Communication Change in Rural Papua New Guinea. Mobile Media and Communication, 4(2): 270-87. doi.org/10.1177/ 2050157915622658 
This text is taken from The Moral Economy of Mobile Phones: Pacific Islands Perspectives, edited by Robert J. Foster and Heather A. Horst, published 2018 by ANU Press, The Australian National University,

Canberra, Australia.

doi.org/10.22459/MEMP.05.2018.04 